\title{
Spiritual Education of Martial Arts as a Solution to Realize Peace in Social Life
}

\author{
Dj Hartono \\ Master of Martial Arts, IAI Al-Khoziny Sidoarjo, Indonesia \\ Email: djoko.hartono@alkhoziny.ac.id
}

\begin{abstract}
Empowerment of spiritual education aims to achieve peace in social life. The contradiction phenomenon is contrary to the intent and purpose of martial arts. The master of martial arts began to indulge an arrogant passion that could cause chaos, commotion and even murder. The existence of martial arts is actually present to be aware of educating young people and Muslims in general to have faith, fear, be able to expose the curtain in the sheath of conscience until they find the pearl of heart enthroned, virtuous, reconcile of brotherhood and mamayu hayuning bawana. The spiritual education of martial arts needs to be returned, applied, and developed in human life, so that can realize the peace in social life.
\end{abstract}

Keywords: Spiritual education, martial arts, peace in social life.

\section{INTRODUCTION}

Education issues are endless and very interesting to discuss. This is because the existence of education that have relationship with science, skills, behavioral and spiritual attitudes become a human need, who called homo sapiens, homo socius, homo religiosus, this is why its existence should be well and professionally managed.

Education is an intangible asset that will become a long-term investment, which if held can give benefits in economic, social and others

Management education in general can also function as a vehicle for students to develop themselves optimally, which regard to aspects of individual, social, aspirations, and potential of other students. Martial arts education as a true asset in the process needs to be managed well and professionally to bring in and make positive contributions. The management process applied can use a series of activities or asset management channels offered by Siregar.
Disputing the spiritual elements that will be empowered in the martial world only leaves the problem of making the martial world secular and the occurrence of humanity, there are many fights, disturbances, killings and other passions. Therefore peace in social life that must be realized becomes rare and expensive.

Based on those conditions, this paper attempts to explore the urgency of spiritual education in martial arts which is the ancestral heritage of the Indonesian people.

\section{METHOD}

This study used a literature review method to reveal how the relationship between the spiritual education of martial arts to the peace of social life. The literatures used include books, articles, and trusted sites. Thereafter comparing various exposures from the literature, phenomenology, linguistics, content analysis, and critical analysis approach to get objective view of empowering spiritual education in martial arts. 


\section{RESULT AND DISCUSSION}

\section{A. Empowering spiritual education}

Martial arts (pencak silat) is formed from two words, pencak and silat. Pencak according to the Big Dictionary Indonesian Language is a game (skill) to defend yourself with the ability to deflect, dodge, and other. The silat is a fighting skill, typical Indonesian martial arts with dexterity to defend themselves and attack for fights [1].

Erwin Setyo Kriswanto also said, martial arts is actually a martial system inherited by ancestors as an Indonesian national culture, has a noble character philosophy that is philosophy that views noble character as the noble source of human attitudes, behaviors and actions needed to realize religious thought and the morality of society, so that humans are aware of their God, improve their quality, place the interests of society above their own interests and love the natural environment [2].

Joko Pamungkas said that currently learning martial arts should consider the purity of the aqidah (spiritual) and scientific aspects, seek friendship, develop inter-college silaturrahmi and other master of martial arts, not to show off, feel best (arrogance), seek praise and hurt others [3]. Maryun Sudirohadiprodjo said, the fighters in conducting martial arts training were educated to rely on the Almighty God, to establish friendship and foster unity [4] Muhammad Taufiq argued, the main target to be achieved in martial arts was to be able to grow, improve the quality of nobility, becomes a carrier and transmitter of the mind, beneficial for citizens and society [5].

Agus Mustofa argued, someone who is spiritualist will be able to possess the nature of God, life goes according to its nature, has a will, becomes wise, has feelings of love and affection, and various divine qualities on a human scale [6].

Imam Junaid, as quoted by M. Turhan Yani, said that interpreting Sufism (spiritual) as morality is a spiritual education that teaches a person to do good, about life in relation to God, fellow human beings and the surrounding environment [7].

Goenawan Mohamad said, learning martial arts is true so as not to fight. As for the fight, spit out "angkoro", namely gross power in a certain negative sense [8]. While in martial arts there is something more than "angkoro". Learning martial arts should be able to make someone more wises. While this wisdom is related to very spiritual spirituality. Spirituality itself grows and develops from the dialectics which increasingly intensely links our bodies with our consciousness.

Muhammad Ibrahim al-Fayumi argued, the existence of spiritual education empowerment would actually be able to realize a movement of peace and calm in the "ukhuwah" system (brotherhood) in social life among human beings [9]. Starting from it, the life of this world will be totally transformed with peace.

The PSHT (Persaudaraan Setia Hati Terate) fighters say, martial arts invites to reveal the veil of conscience where the pearl of life rules without denying all worldly dignity, does not run around on the martial arts lesson as a body education, but continues to dive into in psychiatric education institutions to have as far as everlasting life satisfaction free from the influence of the framework and atmosphere and intending to educate humans, especially its members so that virtuous people know right and wrong, believe and fear God Almighty and aim to join "mamayu hayuning bawana"[10].

\section{B. The method of developing spiritual education in martial arts}

Hartono and Damayanti put forward, as for the methods / methods that can be done to develop spiritual education in Indonesia, among others [11]:

1. Reconstructing the curriculum by developing and internalizing spiritual values in each learning material. 
2. Conduct socialization to develop spiritual education in the following ways and models:

a. Providing workshops to educators to be able to develop spiritual education.

b. Bring spiritual experts in order to sit so that educators are able to develop and internalize the spiritual values of education in every material in learning.

c. Make an agreement or MoU between the educational institutions and educators to develop spiritual education

\section{Urgency to cultivate spiritual education of} martial arts

1. A religious-theocentric approach

According to Ibid, education based on the value of cohesiveness or Sufism can confirm the authenticity of humanity and can realize a moral revolution movement (mental) in society. This group will be the vanguard in the midst of its community and become the leader of the awareness movement in the face of oppression and social storage.

\section{Formal juridical approach}

According to E. Soelasmi, empowering the spiritual education of pencak silat is a form of realizing the opening mandate of the 1945 Constitution which states that, the ideals of this nation are to protect the entire Indonesian nation, and to promote public welfare, educate the life of the nation and carry out world order [12]. According to ibid, in the 1945 Constitution article 31 paragraph 3 yag states that the government strives for and organizes a national education system that increases faith and piety as well as noble character in the framework of educating the life of the nation, which is regulated by law. With the formation of spiritual figure fighters indicating that pencak sialt spiritual education can carry out and carry out the mandate of the law above.

\section{Sociology approach}

In this case, the religious sociologist Joachim Wach argued, as explained by Dadang Kahmad, that, when revealing the spiritual-religious interdependence (interdependence) relationship and society, there was a mutual influence between the two factors [13]. For this reason, the esoteric (spiritual) dimension of a religion or belief can function as a legitimate tool of the process of change that occurs around the life (community) of its adherents.

\section{Cultural approach}

According to Tasmuji, Education and spiritual-religion actually strongly influence cultural changes in society [14]. This is understandable because with education and spiritual-religion an individual can do more and work. The higher education and appreciation / understanding of the spiritual-religious teachings of individuals in society, the higher the culture and civilization they possess. The lower the education and appreciation / understanding of the spiritual-religious teachings of individuals in society, the lower the culture and civilization they possess.

\section{Psychological approach}

"Pesilat" that is met or achieve the needs of self-actualization (selfactualized) as above is the healthiest group. They experience the ultimate experience of spiritual experiences that occur periodically, either vertically or horizontally together as a fulfillment of the need for God Almighty. Maybe some human groups question the rationality of empowering the spiritual education of martial arts as a solution to realize peace in community life. With this psychological explanation, it will at least be a response to some groups who doubt it. In Hick's view, those who do not experience it may be considered irrational and far from objectivity, but those who experience it themselves are rational, and 
the effect can be used as a solution to realize peace in community life [15]. It has been proven throughout history, Sufis / spiritualists when present in the midst of their society always bring shade and peace of life.

\section{Philosophical approach}

The function and benefits of empowering the spiritual education of the martial arts like that have actually been justified by the philosophers. According to James, spiritual practitioners often experience religious experiences that are more like the expression of feelings, which ultimately arises curiosity towards the Creator [16].

\section{Science approach}

When the master of martial art becomes a spiritualist, he will become close to his God. This is as Shah Wali put it, this spirituality causes a person to become close to Allah [17]. Its closeness to God causes it to flow into itself energy (His Nur) and move the brain as a center of control. This brain works based on energy vibrations, and controls all activities. The vibrations that cause a person to do this activity are actually derived from his energy. This is as explained by Erbe Sentanu that, "every human being has inherited in him a tendency that makes his brain thirsty and ready to accept the guidance of 'higher power', namely the power of God Almighty" [18].

\section{CONCLUSION}

Based on the description above, it can be concluded that: empowering the spiritual education of martial arts can be a solution to achieve peace in social life, and the way to empower it is to use a system and process approach.

\section{REFERENCES}

[1] Kamus Besar Bahasa Indonesia, "Pencak", 2016, [accesed on july 26th, 2016, http://kbbi.web.id/pencak].

[2] E. S. Kriswanto, "Pencak Silat: Sejarah dan Perkembangan Pencak Silat, Teknik-Teknik dalam Pencak Silat, Pengetahuan Dasar Pertandingan Pencak Silat”, Yogyakarta: Pustaka Baru Press, 2015.

[3] J. Pamungkas, "Panduan Lengkap Bela Diri dengan Tenaga Dalam: Manfaat Tenaga Dalam Untuk Menjadi Petarung Handa", Yogyakarta: Araska, 2012.

[4] M. Sudirohadiprojo, "Pelajaran Pencak Silat”, Jakarta: Bhratara Karya Aksara, 1982.

[5] M. Taufiq, "Rencana Strategis Pelaksanaan Program Kerja Pengurus Pusat Persaudaraan Setia Hati Terate 2016-2021", Madiun: Pengurus Pusat PSHT, 2016.

[6] A. Mustofa, "Menyelam Samudera Jiwa \& Ruh", Surabaya: Padma Press, 2005.

[7] M. T. Yani, et. al., "Pendidikan Agama Islam: Kontekstual di Perguruan Tinggi", Surabaya: Unesa University Press, 2016.

[8] G. Muhammad, "Serat Purwaka", dalam Jurus Hidup Memenangi Pertarungan", Yogayakarta: Bentang Pustaka, 2016.

[9] Al-Fayumi, M. Ibrahim. "Ibn 'Arabi: Menyingkap Kode dan Menguak Simbol di Balik Paham Wihdat al-Wujud", Jakarta: Erlangga, 2007.

[10] PSHT, "Anggaran Dasar dan Anggaran Rumah Tangga Persaudaraan Setia Hati Terate Pusat Madiun", dalam Keputusan Parapatan Luhur PSHT di Jakarta", Jakarta: PSHT Madiun, 2016.

[11] H. Djoko. "Mengembangkan Spiritual Pendidikan: Upaya Menyiapkan Masyarakat Siap Bersaing di Era Pasar Bebas", Mimbar Pembangunan Agama. No. 353, 2016.

[12] E. Soelasmini, "UUD 1945 Republik Indonesia dan GBHN". Bandung: Wacana Adhitya, 2002.

[13] D. Kahmad, "Sosiologi Agama", Bandung: Remaja Rosdakarya, 2006.

[14] Tasmuji, "Ilmu Alamiah Dasar, Ilmu Sosial Dasar, Ilmu Budaya Dasar". Surabaya: UIN Sunan Ampel Press, 2013.

[15] H. John "An Interpretation of Religion, Human Responses to the Transcendent", New Haven and London: Yale University Press, 1989. 
[16] W. James, "The Varieties of Religious Experience: Pengalaman pengalaman Religius. Terj. Luthfi Anshari”, Yogyakarta: Jendela, 2003.

[17] Al-Dihlawi, S. WaliAllah, "Hujjah Allah alBalighah: Argumen Puncak Allah, Kearifan dan Dimensi Batin Syariat, terj. Nuruddin Hidayat \& C. Romli Bihar Anwar”, Jakarta: Serambi Ilmu Semesta, 2005.

[18] E. Sentanu, "Quantum Ikhlas; Teknologi Aktivasi Kekuatan Hati”, Jakarta: Elex Media Komputindo, 2007. 